\title{
for(e)dialogue
}

Department of Media and Communication

Volume 2, Issue 1: Special Issue (Forced) Migration and Media

How a photograph of a drowned refugee child turned a migrant crisis into a refugee crisis: A comparative discourse analysis

Samuel Parker, Anja Aaheim Naper and Simon Goodman

(p. 12- 28)

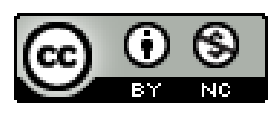

This work is licensed under a

Creative Commons Attribution- Non Commercial 4.0 International License

June 2018 


\section{How a photograph of a drowned refugee child turned a migrant crisis into a refugee crisis: A comparative discourse analysis}

\section{Samuel Parker, Anja Aaheim Naper and Simon Goodman}

Abstract: The 'refugee crisis' refers to the on-going movement of people crossing into Europe, in which over 3,692 migrants and refugees died in 2015. A key point in this 'crisis' was the publishing of photographs of one of the young children who died. Despite the death toll, representations and the resulting treatment of refugees in Europe remained ambivalent. This paper compares the representation of the 'crisis' across three countries (The UK, Norway and Australia) before and after the publishing of the photographs from one major broadcaster in each country using discourse analysis. It is shown that the photographs led to a more sympathetic portrayal of refugees resulting in the 'crisis' shifting from a 'migrant' to a 'refugee crisis'. This analysis demonstrates the importance of the ways in which refugees are presented as well as the benefits of a comparative and interdisciplinary approach to discourse analysis.

Keywords: migrant crisis, refugees, asylum seekers, crisis, discourse analysis, migrants

\section{Introduction}

The 'refugee crisis' refers to the on-going movement of people crossing into, and between, European countries. In many ways, the 'crisis' is nothing new; Pugh (2001) wrote about refugees drowning attempting to cross the Mediterranean back in 2001, however the issue came to prominence in 2015 after media reports of boats sinking attempting the crossing, killing those on board. Indeed, Gatrell (2016) suggests that references to 'crises' fail to take account of the long history of refugee movements and assume that such events are a temporary blip before things return to normal. Hence, in this article we use the term 'crisis' to problematize the media's use of this word. The first time the term 'crisis' was used by the BBC was in April 2015 (Goodman, Sirreyeh and McMahon, 2017). The 'crisis' referred to two main routes of crossing the Mediterranean, one from Turkey to Greece and one from North Africa to Italy (for more on the routes and flows of people, see Crawley et al., 2016). During 2015, as far as known 3,692 refugees died attempting the crossing (IOM, 2015). It has been shown that the type of 'crisis' that is referred to has changed, referring to different locations 
Volume 2, Issue 1: Special Issue (Forced) Migration and Media

and to either refugees or migrants (Goodman et al., 2017) where 'refugee' tends to offer a more sympathetic response than 'immigrant' (e.g. Kirkwood et al., 2015). One key suggestion of Goodman et al. (2017) was that the reporting of the drowning of the three year old boy Alan Kurdi, whose body was photographed washed up on a beach in Turkey, appeared to have an influence on the reporting of the 'crisis', something that this research attempts to investigate further. Specifically, the research questions we sought to answer were as follows. Firstly, did the publishing of the photographs of Alan Kurdi lead to a change in media representations of the 'crisis'? Secondly, were there international differences in these representations? To answer the second question, we chose to focus our analysis on media representations of the 'crisis' in two European countries (The UK and Norway) and one country outside Europe (Australia), which itself has a recent history of migrants and refugees attempting to enter the country by boat.

In the UK, anti-immigration sentiment has been rife, culminating in the 'Brexit' decision to leave the UK at least in part to prevent immigration from the EU, with the 'refugee crisis' being used as a further justification for the decision. Asylum rules in the UK are tough (Bloch, 2013) and asylum figures have remained unaffected by the 'refugee crisis'. Nevertheless, the media and politicians have been shown to be hostile to asylum seeking refugees (e.g. Goodman, 2008). Gabrielatos and Baker (2008) conducted an analysis of a 140 million word corpus of UK newspaper articles about refugees, asylum seekers, immigrants and migrants, published between 1996 and 2005. They found that these terms were frequently confused and conflated and that a number of negative category representations were used in such reports in addition to a number of nonsensical terms such as illegal refugees. More recently, in a comparative study, Berry et al. (2016) found that the right-wing press in the UK was unique in its hostility towards refugees and migrants, whilst the Swedish media was the most positive. Indeed, the Swedish media was found to predominantly use the more sympathetic category of 'refugee', whilst in the UK media 'migrant' was typically used.

In Norway immigration started to rise more recently compared to many other European countries (Brochmann and Kjelstadli, 2014). However, in recent years the number of immigrants arriving (per inhabitant) has been amongst the highest in Europe. During 2015, the number of asylum seekers rose to 30,000, compared to 11,000 in 2014 ( $\varnothing$ vrebye et al., 2016). The general media coverage of migration, and in particular of asylum seekers, has been 
Volume 2, Issue 1: Special Issue (Forced) Migration and Media

dominated by a negative approach, constructing immigrants as threats to 'our' society (Horsti, 2008). However, one of the latest studies on media representations of immigration conducted in Norway, finds an increasing use of a human interest frame in Norwegian articles on immigration, meaning that the focus on one particular person dominates the article, and often this particular person is portrayed in a sympathetic way (Figenschou and Thorbjørnsrud, 2015). For example, a case about a young woman, Maria Amelie, gained massive media attention, and focused on Amelie being a victim of the authorities' inhumane immigration policies.

Debates in Australia around asylum have dominated the public and political sphere for many years, particularly following the 2001 Tampa affair, in which the Australian Government refused to allow a Norwegian ship carrying rescued asylum seekers to enter Australian waters. The subsequent introduction of the 'Pacific Solution' by the Australian Government was in response to both the Tampa affair and the growing concern amongst politicians and the general public about the number of 'boat people' making the crossing from Indonesia. As such, asylum seekers attempting to arrive by boat were transferred to offshore processing centres on Pacific islands such as Nauru and Papua New Guinea where their asylum applications were processed. Off-shore processing was re-introduced by the Labour government in 2012 as a tough response to boat arrivals was espoused. Nguyen and McCallum (2016) indicate that there has been an alignment between Australian news reporting of asylum seekers and government discourse. They conclude that these news reports function to justify the government's hard-line policies as fair and reasonable. A body of research shows that the Australian print media have constructed 'boat people' as illegals, criminals and queue jumpers (Gale, 2004) or as deviants (Pickering, 2001) and that these constructions are predicated on notions of border protection and national identity (Gale, 2004). Other discursive analyses of printed media reports have found a high incidence of water metaphors (floods, tides, swamped etc.) used in Australian media reports about refugees and asylum seekers (Parker, 2015; Nguyen and McCallum, 2016), which add to the construction of asylum seekers as deviants and problems who are a drain on Australian society.

In the section which follows we outline our method of data collection and analysis and then proceed to present a discourse analysis of six articles from the national broadcasters in 
Volume 2, Issue 1: Special Issue (Forced) Migration and Media

the UK, Norway and Australia; three from prior to the publication of the photo of Alan Kurdi and three which followed its publication. We argue that in the week following the publication of the photographs refugees were constructed more sympathetically resulting in the 'crisis' shifting from a 'migrant' to a 'refugee crisis'.

\section{Method}

The death of Alan Kurdi was reported internationally on September 3rd 2015 following his tragic drowning the previous day. Following the suggestion of Goodman et al. (2017) that the reporting of the drowning of Alan Kurdi, who was photographed washed up on a beach in Turkey, appeared to have had an influence on the reporting of the 'crisis', we chose dates that would allow for further investigation of this.

For this study we selected one article that was published in each of the countries from the week before and one from the week following the publication of the photo of Alan Kurdi. This resulted in a sample of six articles for analysis. Each of the articles were selected from the national broadcasters' website in that country: BBC (UK), NRK (Norway) and ABC (Australia). These sources were chosen because each has a good reputation, national coverage and aim to present a range of views with impartiality, thus allowing for international comparison. The articles were chosen following a keyword search of all the articles on refugees, asylum seekers and migrants published on the broadcaster's website within the given time span, based on the criterion that each article prior to and after the publishing should deal with similar situations.

The six selected articles were coded for sections referring to the 'crisis', and extracts selected for examination using discourse analysis (McKinlay and McVittie, 2009). As this was a discursive analysis our focus is on what is accomplished in each of the articles analysed, rather than seeing them as a route to understanding what the author may or may not have been thinking (Edwards and Potter, 1992).

\section{Analysis}

In this analysis we begin by demonstrating how the construction of the 'crisis' differed between media reports in each of the three countries before and after the publication of the photo of Alan Kurdi's drowning. This is followed by a more general, and comparative 
Volume 2, Issue 1: Special Issue (Forced) Migration and Media

discussion regarding the use of language in constructing the 'crisis' following the publication of the photo.

\subsection{The UK}

This analysis addresses one article from the BBC a week before and after the publishing of the photographs of Alan Kurdi. This first example published a week before, also focuses on the tragic death of refugees crossing the Mediterranean.

\section{Migrant crisis: Scores of bodies found on Libya boat ${ }^{1}$}

2. [Europe Migrant Crisis]

3. About $\mathbf{5 0}$ people have been found dead in the hold of a boat carrying

4. migrants intercepted off the coast of Libya, the Italian coastguard says.

5. Thousands of migrants have died and many thousands more have been rescued

6. after setting sail from Libya recently.

7. Wednesday's rescue operation was one of 10 such missions currently taking

8. place in the waters off Libya, the Italian coastguard said

9. Ahead of the summit, Austrian Foreign Minister Sebastian Kurz told the BBC

10. that current EU asylum regulations were not working.

11. Earlier in the week, Macedonian police had to use stun grenades after thousands

12. of migrants broke through police lines at the Greek border.

This first thing to note in this example is that this is explicitly referred to as a 'Migrant crisis' (1), which categorises those who died as migrants, rather than as refugees. This article makes no reference to 'refugees' at any point, with the term 'migrant' used throughout. 'Migrant' has been shown to be a negative term when compared with refugee, particularly as this ignores the specific needs of refugees who have been forced to flee their homes because of a fear for their safety (see Goodman and Speer, 2007). The article itself is categorised as 'Europe Migrant Crisis'. This term works to present the 'crisis' as one for Europe rather than for the people attempting to reach Europe (see Goodman, et al., 2017), many of whom are reported to have suffocated in this article.

The migrants in this article generally lack agency to act themselves, so that they are 'intercepted' (4) and either died (5) or are 'rescued' (5), whereas it is the Europeans (here 
Volume 2, Issue 1: Special Issue (Forced) Migration and Media

Italians) who have agency. However, where migrants are shown to have agency they are shown to have 'broke through police lines' (12) which is problematic, as it associates them with criminal behaviour. This kind of portrayal helps to justify the use of violence ('had to use stun grenades' (11) towards those who are categorised in this article as 'migrants'.

In sum, although people are reported to be dying in their attempts to reach Europe, they are also positioned as problems and as such in need of keeping out; as 'illegal' migrants and not refugees. The following article was published a week after the photographs of Alan Kurdi were published and presents a more sympathetic approach.

\section{Migrant crisis: EU's Juncker announces refugee quota plan ${ }^{2}$}

2. European Commission President Jean-Claude Juncker has announced plans

3. that he says will offer a "swift, determined and comprehensive" response to

4. Europe's migrant crisis.

5. Under the proposals, 120,000 additional asylum seekers will be distributed

6. among EU nations, with binding quotas.

7. He said tackling the crisis was "a matter of humanity and human dignity. It is true

8. that Europe cannot house all the misery in the world. But we have to put it into

9. perspective.

10. "This still represents just $0.11 \%$ of the EU population. In Lebanon refugees

11. represent $25 \%$ of the population."

12. A note on terminology: The $B B C$ uses the term migrant to refer to all people on

13. the move who have yet to complete the legal process of claiming asylum. This

14. group includes people fleeing war-torn countries such as Syria, who are likely to

15. be granted refugee status, as well as people who are seeking jobs and better

16. lives, who governments are likely to rule are economic migrants.

This article is prefixed with the heading 'migrant crisis' (1), and like the previous extract is categorised as being part of the 'Europe Migrant Crisis' series, so this is very much framed around migration. Also, as with the previous example, the 'migrant crisis' is referred to as 'Europe's' (4). However, unlike the previous example there are also references to refugees throughout the article, including in the title (1), in addition to use of the category 'migrant'. Another major difference compared to the previous article is the reference to 'humanity' (7) 
Volume 2, Issue 1: Special Issue (Forced) Migration and Media

which positions this story as being about people in need of support, rather than simply exclusion and works to counter dehumanising representations. The President of the EU Commission, whose statement this article is based around presents a broadly sympathetic portrayal of refugees, suggesting that Europe should be offering support to refugees and constructs Europe as a trustworthy caring entity, responsible for making rational just decisions.

Of particular relevance is the footnote to the article (found on most, but not all 'Europe Migrant Crisis' articles of the day) which explicitly topicalises terminology (12-16). Here the BBC justifies and rationalises its use of terms, claiming that 'migrant' (12) is a catch all term that may include refugees, asylum seekers and economic migrants. This note functions as a disclaimer, and suggests that the writer of this policy is managing a possible dilemma (Billig et al., 1988) where using the label of either migrant or refugee may be interpreted as taking a specific stance, particularly regarding the status of the refugees. 'People on the move' (1213 ) is value free regarding people's refugee status, and the reference to 'legal process' helps to defer the responsibility defining status from the BBC to individual countries' laws. While the note does not refer to any of the migrants as 'refugees' the term is nevertheless used to refer to a 'likely' status; equally economic migrant (16) is presented as a possible category for the migrants, but in both cases the note remains ambiguous and leaves the final decision to 'governments' (16) who make the rulings. This note was not found on articles predating the photographs of Alan Kurdi being published. While this note explicitly does not call the people referred to in this article refugees, it does make the category available in a way that was not done previously, meaning that the possibility that these people are refugees is now implied.

While this article is still headed under the banner of 'Europe Migrant Crisis', the overall tone of this article is very different from the previous one. Whereas the article predating the death of Alan Kurdi presented refugees as problematic people to be excluded, the article after his death presents them as requiring humanitarian support. Alan Kurdi is not referenced in this article (only a link to another article about him remains), but it is possible that the impact of the publicising of his death can be seen in the references to refugees and humanitarianism that were absent in the previous article. 
Volume 2, Issue 1: Special Issue (Forced) Migration and Media

\subsection{Norway}

This analysis addresses two articles from NRK, a week before and after the publishing of the photographs of Alan Kurdi. The article from the 26 August is on refugees crossing borders in Europe and is categorized as being about "refugees in Europe", partly implying this to be a European issue.

\section{Crawling in to Hungary under the barbed wire fence ${ }^{3}$}

2. [Refugees in Europe]

3. This morning, many Syrian refugees crawled under the barbed wire fence that is

4. put up between Hungary and Serbia.

5. Look at the refugees crawling under the barbed wire fence here.

6. Hungarian authorities have put up a barbed wire fence, but the fence shows

7. great deficiencies. The refugees were helping each other holding the lowermost

8. part of the fence, while others were crawling under it.

9. During August, the stream of refugees from Serbia to Hungary has increased. On

10. Monday, the number of border crossings was the highest ever. 2093 persons

11. crossed the border. In 2015, Hungary has registered over 100000 migrants.

12. This border is the outermost border of the Schengen area, and when they have

13. entered Hungary, they can travel freely to any of Schengen's 26 countries.

14. "If we do not take consequential steps, we will become a lifeboat sinking

15. underneath the weight of those struggling to hold on to it" says Janos Lazor.

16. "The decision to protect the borders of Hungary will be made next week"

17. spokesperson of the government, Zoltan Kovacs says.

In the article, the situation is through metaphors, depicted to be one of invasion and conflict, protecting an inside from an invading outside. Water metaphors (9) imply that an uncontrollable force is approaching the borders, which calls for a concrete answer such as a need for protection (16). By drawing on this repertoire, the refugees' need for protection is also undermined in favor of the border's need for protection.

Through using the metaphor of a sinking lifeboat (14-15), normally associated with the disastrous deaths of refugees in the Mediterranean, the Hungarian politician equates the situation of the Hungarian people and Europe with the situation of the fleeing refugees. 
Volume 2, Issue 1: Special Issue (Forced) Migration and Media

Consequently, it is implied that the current situation for the people of Hungary is just as desperate as the situation for the refugees fleeing. This contributes to the justification of the fence, as well as implying the 'crisis' to be a European one, rather than one outside Europe.

The agents in the articles are both the Hungarian government working to secure the border, and the refugees themselves, finding ways to bypass it, despite Hungary's effort to protect it (6-8). Although the refugees' act is not entirely a negative one, as for example "helping" implies humanity, it is also suggesting illegality and helps justify the need for securing the border. Hence, the agency of the refugees is partly portrayed as being negative.

In the article, the term 'migrant' is only used once (11), and the term 'refugee' is used nine times. The terms are not connected or used in the same sentence, which makes the distinction between them unclear, but there is a fact box attached where the difference between 'migrants' and 'refugees' is underlined. Thus, there seem to have been a rather conscious use of the terms migrant and refugee in this article. As the term refugee connotes people in need of protection, it creates ambiguity in relation to how to respond to the "stream of refugees", and who actually is in need of protection: the refugees or the border. The term 'person' (10) is used once, when addressing the number of people crossing the border between Serbia and Hungary. This functions to promote the refugees as equals; everybody is a "person", whilst not everybody can be labelled a migrant or a refugee.

The next article is also on border crossings, but these border crossings unfold closer to Norway.

\section{3000 refugees arriving in Denmark during three days - full stop in the ferry and} train traffic ${ }^{4}$

2. According to the Danish Police, there were around 3000 foreigners arriving in

3. Denmark between Sunday and Wednesday. The situation is

4. changing hour by hour. "We have a difficult task managing all the people who

5. are entering. We are talking about humans, families and children who

6. have travelled a long way trying to escape areas of war and conflict. We must

7. handle this situation through dialogue and understanding" says Svend Larsen in the Danish Police.

8. Several ferries and trains with refugees and migrants arrived yesterday. 
Volume 2, Issue 1: Special Issue (Forced) Migration and Media

9. While the refugees are sitting in the train waiting, a stream of Danes are coming

10. to help. They bring cloths, food and beverages.

11. The refugees are entering Rødbyhavn, Lolland, and the border

12. town of Padborg, Jylland. Here, the refugees are asked to register in Denmark,

13. as asylum seekers. Most of them say no. They want to go to Sweden. - We

14. hope to convince them that the most reasonable thing to do is to register,

15. says Carsen Andersen.

16. Sweden is not interested in receiving those refugees wanting to go to Sweden

17. but already in Denmark. That was made clear after a meeting between Swedish

18. and Danish authorities.

The second article, published on the 9 September, deals with the same situation, a high number of refugees (1-2) crossing a border, this time between Denmark and Sweden. The situation is presented as chaotic (4); however, this article focuses on management and finding ways to distribute the refugees between the two countries (12-18). Thus, a management and humanitarian theme, which in itself is a more positive approach, has challenged the conflict theme above.

The people quoted in this article are all police officers emphasizing that the refugees are vulnerable humans (5-7). As the police are often associated with criminality and control, this police statement about human compassion serves to strengthen the humanitarian discourse. However, the police officers also victimize the refugees, implying that they are not reasonable (14). Thus, 'othering' processes are at work as well, even though this approach is a more positive one than the former.

The terms used for the people on the move are asylum seekers, migrants, humans, foreigners and children, but first and foremost they are labelled as refugees. The term migrant is also used, but in this article, the term migrant is only used to distinguish from the refugee (8). This clear distinction, as well as describing them as humans trying to escape war, works to present them as more deserving than what was the case in the first article. This quote also implies that the real 'crisis', the war, is not happening in Europe, but rather outside.

The humanitarian angle is also detectable when describing the "stream of Danes" (9-10) as a concrete Danish response to the notion of the "stream of refugees" entering. But rather 
Volume 2, Issue 1: Special Issue (Forced) Migration and Media

than promoting an understanding of the refugees' situation, this works to provide an idea of the benign Dane, helping people in need and managing the refugee situation.

To sum up, the use of terms only differs slightly in the two articles, but overall there seem to have been a rather conscious use of the terms migrant and refugee in both articles. However, there was a higher focus on management and humanitarianism rather than conflict in the article after Alan Kurdi's death, as well an increased focus on concrete solutions.

\subsection{Australia}

This analysis addresses one article from the $A B C$ a week before and after the publishing of the photographs of Alan Kurdi. This first example, taken from a week before, focuses on the number of refugees crossing the Mediterranean in 2015 and is predominantly informed by quotes from a UN High Commissioner for Refugees (UNHCR) spokesperson.

\section{Up to 3,000 refugees, migrants expected every day in Macedonia, UNHCR says ${ }^{5}$}

2. Up to 3,000 migrants are expected to cross into Macedonia every day in the

3. coming months, most of them refugees fleeing war, particularly from Syria, the

4. United Nations has said.

5. "They are coming in large groups of 300 to 400 people and then travelling

6. onwards by train or bus to Serbia" UNHCR spokeswoman Melissa Fleming told

7. a news briefing.

8. "We are anticipating that this influx and this route is going to continue at the

9. rate of up to 3,000 people per day," she said.

10. Ongoing violence in Iraq and Syria and "worsening conditions" for Syrian

11. refugees in Turkey, Jordan and Lebanon are driving people to seek asylum

12. in Europe, Ms Fleming said.

In this article a variety of terms are used to categorise those crossing the Mediterranean. The term 'migrant' is used on four occasions and, on each occasion, is used in the same sentence as the category 'refugee' (1), making it unclear whether the 'crisis' is being constructed as a 'refugee crisis' or a 'migrant crisis'. By contrast the term 'asylum seeker' is also used four times in the article but not in the same sentence as the terms 'refugee' or 'migrant', suggesting that they were being used interchangeably. Such a discursive strategy 
Volume 2, Issue 1: Special Issue (Forced) Migration and Media

creates ambiguity between the categories of 'migrant' and 'refugee' and therefore leads to a dilemma in what the appropriate response to the 'crisis' should be. The term 'people' (a value free term, as discussed above) is also used seven times in this article, almost exclusively when quantification is used (5). This quantification rhetoric functions to construct the 'crisis' as an exclusively 'EU crisis' with no mention of Australia's response, shown in the large numbers of people entering EU countries each day $(1,2,5,9)$. When used with water metaphors (see Van der Valk, 2003), such as "influx" (8) this quantification rhetoric implies that the 'crisis' is a temporary problem, for the EU, but not for Australia.

Here, refugees do have agency as they are fleeing (3) or travelling (5) to Europe, and whilst a number of water metaphors (8) and disaster metaphors (10) were found throughout the article, echoing previous findings of their use in Australian media reporting on refugees and asylum seekers (Nguyen and McCallum, 2016), this is done through a humanitarian, rather than, a conflict discourse. However, this may be because much of the article is based on quotes from UNHCR. As such, use of these metaphors helps to construct the 'crisis' as an EU problem, as it is the EU who must respond to this "influx" (8). By drawing on a humanitarian repertoire it positions refugees as deserving, which has often been found to be absent in Australian media reporting on asylum seekers and refugees attempting to enter Australia by boat (Pickering, 2001; Gale, 2004).

The article analysed from the 7th of September 2015 showed some similarities with the article of the week before Alan Kurdi's drowning. Its main difference is in its framing of the 'crisis'.

\section{Syrian refugee crisis: We're failing to do our part ${ }^{6}$}

2. While the Opposition has called for a one-off life to Australia's refugee intake,

3. the Prime Minister hasn't budged. No matter which way you cut it, Australia

4. isn't stepping up to the plate, writes Monica Attard.

5. We are a long way from the source of the crisis. We have and continue to do

6. something, albeit not enough, to resettle refugees who are forced to flee their

7. homes. But we are a long way from acting swiftly to help relieve the raw,

8. palpable suffering of the Syrian asylum seekers as Germany and Austria have

9. done, not to mention doing what a good global citizen does to help out the 
Volume 2, Issue 1: Special Issue (Forced) Migration and Media

\section{European nations bearing the burden of proximity.}

\section{What a pity-for the asylum seekers and for us.}

Here, in contrast to the previous article, the 'crisis' is framed as a 'Syrian refugee crisis' (1) with only the terms 'refugee' (five occurrences) and 'asylum seeker' (ten occurrences) being used. The term 'migrant' is not used at all in this article. By focusing on humanitarian discourses (6-10) and framing the article as a 'Syrian refugee crisis', refugees and asylum seekers are positioned as those who have fled their homes and therefore as those who are deserving of support. However, by framing the 'crisis' as a 'Syrian refugee crisis' this article also fails to recognise that many of the refugees are not Syrians but are from other countries in the Middle East and Africa. Such a framing therefore positions those who are not Syrian refugees as less deserving of sympathy and support and leads to their status being open to question. Similarly, framing the 'crisis' as solely a 'Syrian refugee crisis' suggests that it is a temporary phenomenon, which will end once a resolution to the Syrian civil war is found. It fails to take account of wider global trends in forced migration.

Further rhetorical work is achieved in this article through the use of the pronoun "we". Through its multiple uses a dilemma (Billig et al., 1988) is apparent because "we" positions Australia (and Australians) as failing to play its (their) part (7) whilst also acknowledging distance from the source of the 'crisis' (5). Thus, in line with the previous article, the 'crisis' is positioned as an EU problem, however, here it is one which Australia should be assisting in solving. Indeed, the humanitarian repertoire used in this article further serves to criticise the Australian government's history of responding to refugees and asylum seekers who attempt to enter Australia by boat

In sum, this article has an increased humanitarian focus than the first article, and whilst both, to an extent, do construct asylum seekers and refugees as deserving, the biggest difference lies in the use of terms and the framing of the 'crisis'. In both articles, perhaps because of Australia's geographic location, the 'crisis' is positioned as an EU problem, so that it is Europe which needs help rather than those attempting to enter Europe, and there is no discussion of the role which Australia could play in resolving the 'crisis'. It is also interesting that the term 'migrant' was not used at all in this article following the publication of the photograph of Alan Kurdi and that it is framed as a 'Syrian refugee crisis', rather than just a 
Volume 2, Issue 1: Special Issue (Forced) Migration and Media

'refugee crisis'. Such a framing of the 'crisis' is exclusionary and positions Syrian refugees as deserving whilst, other conflict-affected migrants and refugees, are excluded.

\section{Discussion}

The aim of this research was to analyse whether the reporting of the drowning of Alan Kurdi, who was photographed washed up on a beach in Turkey, had an influence on the reporting of the 'crisis' in three different countries.

Taking a comparative discourse analysis approach has demonstrated that in each of the three countries a variety of terms were used to categorise those crossing the Mediterranean to Europe: 'migrant', 'refugee', 'asylum seeker', 'person' and 'foreigner'. The category 'migrant' has been shown to be more negative than that of 'refugee' (Goodman and Speer, 2007) and, before the publication of Alan Kurdi's photograph, was the only term used in the UK article. In the Australian article, however, the terms 'migrant' and 'refugee' appeared to be used interchangeably and appeared in the same sentence whenever either was used. In the Norwegian article, the more positive term 'refugee' was used almost exclusively, which functioned to create ambiguity between humanitarian and security discourses. Despite this, in each of the articles the 'crisis' was constructed as being 'Europe's crisis', rather than a 'crisis' for those who are trying to reach Europe. This construction is problematic because it overlooks the specific needs that refugees may have as a result of fleeing their home countries and creates a discourse in which security and border protection takes precedence over the welfare of refugees.

Following the publication of the photograph of Alan Kurdi there were some noticeable changes in the use of terms. The second Australian article did not use the term 'migrant' at all, instead opting for the more positive terms 'refugee' or 'asylum seeker'. In the UK and Norwegian articles the term 'refugee' was more frequently used, and whilst the term 'migrant' was still used, there were attempts made to draw a distinction between the two categories in order to present 'refugees' as more deserving. Of particular interest here is the BBC's addition of an explanation on terminology, which functioned as a disclaimer and suggested a possible dilemma (Billig et al., 1988) around the use of the term representing a specific stance. This analysis has therefore demonstrated the ways in which a category is used is never neutral, as different terms present those described in different ways. In this case the 
Volume 2, Issue 1: Special Issue (Forced) Migration and Media

analysis has demonstrated that the publishing of the pictures of Alan Kurdi led to a change in the category use from the more negative 'migrant' to the more positive and 'deserving' 'refugee' in all three countries' media.

Taking a discursive approach further highlighted that in the articles before the photos of Alan Kurdi were published, refugees were portrayed as generally lacking agency, and where they were given agency this was shown in negative terms which threatened borders and state security. An exception to this was in the Australian article where, despite the confusion over terms, the agency of refugees was constructed under a humanitarian repertoire. However, Australia's geographic distance from the 'crisis' may be a reason for this as previous research has shown that refugees and asylum seekers attempting to enter Australia have typically been constructed using security and deviance discourses (Pickering, 2001; Parker, 2015).

\section{Bibliography}

Berry, M., Garcia-Blanco, I. and Moore, K. (2016). Press coverage of the refugee and migrant crisis in the EU: a content analysis of five European countries. UNHCR.

Billig, M., Condor, S., Edwards, D., Gane, M., Middleton, D., and Radley, A. (1988). Ideological dilemmas: A social psychology of everyday thinking. London, England: Sage.

Bloch, A. (2013). "Living in fear: rejected asylum seekers living as irregular migrants in England", Journal of Ethnic and Migration Studies, Volume 40, Issue 10, pp.1507-25.

Brochmann, G. og Kjeldstadli, K. (2014). Innvandringen til Norge 900-2010 Oslo, Pax.

Crawley, H., Duvell, F., Sigona, N., McMahon, S. and Jones K. (2016). Unpacking a rapidly changing scenario: migration flows, routes and trajectories across the Mediterranean, Research Brief No. 1, http://www.medmig.info/wp-content/uploads/2016/03/MEDMIG-Briefing-01-March-2016FINAL-1.pdf.

Edwards, D., and Potter, J. (1992). Discursive Psychology. London, England: Sage.

Figenschou, T.U. and Thorbjørnsrud, K. (2015). "Faces of an Invisible Population: Human Interest Framing of Irregular Immigration News in the United States, France, and Norway" American Behavioural Scientist. Volume. 59.

Gabrielatos, C. and Baker, P. (2008). Fleeing, Sneaking, Flooding A Corpus Analysis of Discursive Constructions of Refugees and Asylum Seekers in the UK Press, 1996-2005. Journal of English Linguistics Volume 36, Issue 1, pp. 5-38.

Gale, P. (2004). The refugee crisis and fear: Populist politics and media discourse. Journal of Sociology Volume 40, Issue 4, pp. 321-340. 
Volume 2, Issue 1: Special Issue (Forced) Migration and Media

Gatrell, P. (2016). Refugees-What's Wrong with History? Journal of Refugee Studies. DOI: $10.1093 /$ jrs/few013

Goodman, S. (2008). Justifying harsh treatment of asylum seekers through the support of social cohesion. Annual Review of Critical Psychology, Volume 6, pp. 110-124.

Goodman, S., Sirreyeh, A. and McMahon, S. (2017). The evolving (re) categorisations of refugees throughout the "refugee/migrant crisis". Journal of Community \& Applied Social Psychology Volume 27, Issue 2, pp. 105-114.

Goodman, S. and Speer, S. (2007). Category use in the construction of asylum seekers. Critical Discourse Studies, Volume 4, pp.165-186. doi:10.1080/17405900701464832.

Horsti, K. (2008). Overview of Nordic Media Research on Immigration and Ethnic Relations From Text Analysis to the Study of Production, Use and Reception Nordicom Review 29, 2 pp. 275-293.

IOM (International Organisation for Migration) (2015). Irregular Migrant, Refugee Arrivals in Europe Top One Million in 2015: IOM. Available from https://www.iom.int/news/irregular-migrantrefugee-arrivals-europe-top-one-million-2015-iom.

Kirkwood, S., Goodman, S., McVittie, C. and McKinlay, A. (2015). The language of asylum: Refugees and discourse. London, England: Palgrave.

McKinlay, A. and McVittie, C. (2009). Social psychology and discourse. Sussex, England: WileyBlackwell.

Nguyen, L. and McCallum, K. (2016). Drowning in our own home: a metaphor-led discourse analysis of Australian news media reporting on maritime asylum seekers. Communication Research and Practice Volume 2, Issue 2, pp. 159-176.

$\varnothing$ vrebye, E., Stjernø, S. and Halvorsen, K. (2016). Innføring I helse- og sosialpolitikk Oslo, Universitetsforlaget.

Parker, S. (2015). 'Unwanted invaders': The representation of refugees and asylum seekers in the UK and Australian print media. eSharp 23.

Pickering, S. (2001). Common sense and original deviancy: news discourses and asylum seekers in Australia. Journal of Refugee Studies Volume 14, Issue 2, pp. 169-186.

Pugh, M. (2001). Mediterranean boat people: a case for co-operation? Mediterranean Politics, Volume 6, Issue 1, 1-20. doi: 10.1080/713604489.

Van Der Valk, I. (2003). Right-Wing Parliamentary Discourse on Immigration in France. Discourse and Society Volume 14, Issue 3, 309-348. doi: 10.1177/09579265030143004. 


\section{Biographies}

Sam Parker is an ESRC-funded PhD candidate in the School of Social Sciences at Cardiff University. His PhD research looks at the ways in which asylum seekers and refugees talk about integrating in Wales.

Anja Aaheim Naper is a PhD candidate at Oslo and Akershus University College. She is writing her PhD on how migration control is understood and portrayed in Scandinavian news media during the so-called refugee crisis in 2015.

Simon Goodman is a Research Fellow at Coventry University. His research addresses the discursive construction of asylum seekers and refugees both in media debates and in the talk of refugees themselves.

\footnotetext{
${ }^{1}$ http://www.bbc.co.uk/news/world-europe-34066466 26 August 2015 (accessed 8 November 2017)

${ }^{2}$ http://www.bbc.co.uk/news/world-europe-34193568 9 September 2015 (accessed 8 November 2017)

${ }^{3}$ https://www.nrk.no/urix/krabber-under-piggtradgjerdet-og-inn-i-ungarn-1.12518642 26 August 2015. (Accessed from Atekst Retriever, 5 August, 2016)

${ }^{4} \mathrm{https://www.nrk.no/urix/3000-flyktninger-til-danmark-pa-3-dager-1.12543573} 9$ September, 2015. (Accessed from Atekst Retriever, 5 August 2016)

${ }^{5}$ http://www.abc.net.au/news/2015-08-26/up-to-3000-refugees-migrants-expected-a-day-in-

macedonia/6724988 26th August 2015 (accessed 8 November 2017)

${ }^{6}$ http://www.abc.net.au/news/2015-09-07/attard-we're-not-'stepping-up-to-the-plate'-on-syria/6755154 7th

September 2015 (accessed 8 November 2017)
} 
Contact author(s):

Samuel Parker

ParkerS16@cardiff.ac.uk

Anja Aaheim Naper

anja.naper@hioa.no

Dr Simon Goodman

aa4592@coventry.ac.uk 